\title{
From Novelty Act to National Association: The Emergence of Ladies' Gaelic Football in the 1970s
}

\author{
Hayley Kilgallon \\ M.A., School of History, University College Dublin \\ Dublin, Ireland
}

(C) Hayley Kilgallon. This work is licensed under the Creative Commons Attribution-NonCommercialNoDerivatives 4.0 International License. To view a copy of this license, visit http://creativecommons.org/licenses/by-nc-nd/4.0/.

\begin{abstract}
In 1967 a county Cork farmer wrote to the Sunday Independent (Dublin) to express his hope that the Gaelic Athletic Association (G.A.A.) would ban women from attending the upcoming All-Ireland finals. The G.A.A is a male-only organisation, he argued, and the presence of women at Croke Park would take up 'valuable space'. His letter generated many outraged responses from both men and women, all arguing against his opinion and illustrating that women played a vital role within the sporting community-whether as supporters, sandwich-makers or jersey-washers. The responses highlighted how people in Ireland were reconsidering the role of women in the public sphere more generally in the late 1960s. The emergence of ladies' Gaelic football as a 'serious' sport for women in the 1970s is reflective of this changing society. Current Irish sports historiography is considerably lacking in its examination of the space women occupied in modern sport in Ireland. This piece will draw on newspapers and archival material to examine the emergence of what came to be known as ladies' Gaelic football in the late 1960s and early 1970s and to analyse the debates about the changing position of women in sport and society at this time. In so doing, this piece will aim to bring the historiography of women in Irish society in conversation with the growing historiography on sport in Ireland.
\end{abstract}

Keywords: Women's sports; Ladies' Gaelic football; Ladies' Gaelic Football Association; Irish society

\section{Introduction}

In July 1974, less than fifty years ago, a small group of people met in Hayes Hotel, Thurles, county Tipperary, with the aim of founding a national association for the organisation and promotion of the game they termed ladies' Gaelic football. ${ }^{1}$ The game had gained prominence in the late 1960s and early 1970s at carnivals and festivals around Ireland and was often described as a novelty attraction in local newspapers publicising the festivities. ${ }^{2}$ The founding of the Ladies' Gaelic Football Association (L.G.F.A.) was a major development in the history

\footnotetext{
${ }^{1}$ Account written by Francis Quill and Pat Chapman, 'Where did it all begin? The initial history of An Cumann Peil Gael na mBan up to 1974', 2006, private papers of Marie McAleer.

${ }^{2}$ Examples of local newspapers reporting in this way include: 'Seventh Annual Field Evening', Meath Chronicle, 8 June 1968, 14; 'Falcarragh Festival Fortnight', Donegal News, 6 July 1968, 2; 'Farranfore sports meeting is being revived on Sunday', Kerryman, 14 September 1968, 18; 'Portarlington', Nationalist and Leinster Times, 8 August 1969, 6; 'No shortage of novelty events', Drogheda Independent, 14 August $1970,16$.
} 
of sport in Ireland; for the first time a national governing body would actively manage and facilitate the playing of Gaelic football for women in Ireland. The choice of venue for the first meeting of the L.G.F.A. was symbolic as it was the same place in which the Gaelic Athletic Association (G.A.A.) had been established in November 1884. It was not surprising that the G.A.A. did not make any competitive provision for women in their activities when the association was founded. The social norms of the late nineteenth and early twentieth centuries dictated that women and physical contact team sports were broadly incompatible. Women, it was argued, were biologically inferior to men and were more suited to less physical pursuits and those that favoured aesthetic and less strenuous components. ${ }^{3}$ As a result, historian Jennifer Hargreaves suggests that women's participation in sport in this period generally 'embodied the characteristics of passivity rather than activity, subordination rather than ascendency'. 4 However, that is not to say that women were not involved or interested in sport. Allen Guttmann has demonstrated in his work that women have never been completely excluded from sport, though, until recently, they have not been afforded the same opportunities as men in sport. ${ }^{5}$ In Ireland, Tom Hunt's examination of women and sport in Victorian Westmeath indicates that women of all classes regularly attended race meetings and regattas as well as cricket games and Gaelic football matches. ${ }^{6}$ The presence of women as spectators at Gaelic football and hurling matches in the 1880s and 1890s was reported to be sizeable and was welcomed by the G.A.A., who often admitted women at a discount or for free. ${ }^{7}$ Nevertheless, there is no doubt that women have occupied a place more complex than that of passive spectator or consumer within the world of sport than is generally suggested. Women's relationship with sport is much more nuanced, not just because of gender stereotypes but also because of class standing, social and gender inequality, religious teaching, and medical beliefs.

The historiography of Irish sport is significantly wanting in examining the history of women and sport in Ireland. In particular, the history of women in the G.A.A. is underresearched. Traditionally holding the roles of playing kit-washer, sandwich-maker, and dutiful supporter of the menfolk, women's opportunities on the field of play were limited. Camogie, a stick game adapted from hurling for women, was the only officially-organised channel through which women could practice Gaelic games. Stick games similar to camogie, like golf and hockey, had become popular amongst women in the late 1800s and organising bodies for women's golf and hockey were formed in 1893 and 1894 respectively. These sports were deemed relatively acceptable for women to play as they were considered less strenuous and less dangerous than a physical contact game like football. The Camogie Association was founded in 1905 and was closely linked with the Gaelic League, a cultural organisation formed in 1893 with the aim of reviving the Irish language, and the Camogie Association used their branches to promote camogie and establish clubs throughout the country. ${ }^{8}$ The growth of ladies' Gaelic football into a competitive and formally-regulated sport was aided by changing mores in the Republic of Ireland in the late 1960s and 1970s, as well as the increase in female

\footnotetext{
${ }^{3}$ Jennifer Hargreaves, 'The Victorian Cult of the Family and the Early Years of Female Sport', in The Sports Process, eds. Eric G. Dunning, Joseph A. Maguire and Robert E. Pearton (Champaign: Human Kinetics Publishers, 1993), 54.

${ }^{4}$ Hargreaves, 'The Victorian Cult of the Family', 56.

${ }^{5}$ Allen Guttmann, 'Sport, Politics and the Engaged Historian', Journal of Contemporary History 38, no. 3 (2003): 371.

${ }^{6}$ Tom Hunt, 'Women and Sport in Victorian Westmeath', Irish Economic and Social History 34, no. 1 (2007): 31-34.

${ }^{7}$ Regina Fitzpatrick, Paul Rouse and Dónal McAnallen, 'The Freedom of the Field: Camogie before 1950', in The Evolution of the GAA: Ulaidh, Ére agus Eile, eds. Dónal McAnallen, David Hassan and Roddy Hegarty (Belfast: Ulster Historical Foundation, 2009), 123.

${ }^{8}$ Mike Cronin, Mark Duncan and Paul Rouse, The G.A.A.: A People's History (Cork: The Collins Press, 2009), 323.
} 
participation in team sports and ball games more generally worldwide. While there is a growing historiography exploring the changing role of women in Irish society in this period, much of it is concerned with the Second Wave Women's Movement and progress made at a statutory level in creating greater gender equality. Relatively little attention has been paid to how women's everyday lives were changing at this time.

Opinions on women's participation or interest in sport were illustrated in various ways, notably in national newspapers. For example, in the 1950s and 1960s, letters decried Maeve Kyle's Olympic participation and women's involvement in certain physical activities. Gaelic football, too, became the focus. A letter from a farmer in county Cork published by the Sunday Independent (Dublin) in August 1967 presented the conservative view that a woman's place was in the home. In the letter, the farmer expressed his hope that the G.A.A. would ban women from attending the upcoming All-Ireland finals. The G.A.A. was a male-only organisation, he argued, and the presence of women in Croke Park would take up 'valuable space'. He went further, stating that the sight of a 'pleasure-bent woman up in the city for fun and enjoyment, instead of being satisfied with her lot at home' was, to him, both 'revolting' and 'unnatural'. Whether the G.A.A. agreed with this assessment was unclear. Given the existing norms and social mores, it is likely that the farmer wasn't alone in his opinion that the G.A.A. was 'for men only'. In post-independence Ireland, girls were taught to aspire to marriage and childrearing, or to religious life, and that the world of work was a solitary and lowly way of life for a woman. ${ }^{10}$ This was reflected in the fact that in 1966, only five percent of working women were married; ${ }^{11}$ women were outnumbered two to one by men at Irish universities in the latesixties. ${ }^{12}$ The Marriage Bar, a ban imposed on women from continuing in paid employment once they married, also promoted the view that a woman's place was in the home. The ban was removed for teachers in 1957 but stayed in place for civil servants until 1973. ${ }^{13}$ Diarmaid Ferriter affirms that 'Ireland matured greatly in the 1960s', ${ }^{14}$ and it is significant that the farmer's letter generated a heated response from both men and women, all arguing against his position. The disagreeing correspondents were 'horrified' by the farmer's 'out-dated idea' and reminded the farmer that women 'are human beings, not mechanical instruments' and they do not want to be 'tied body and soul to a house'. The views and facts above illustrate how pervasive gender roles were at many different levels in twentieth-century society in Ireland.

By using sport as a medium to examine the social attitudes towards women in society, this piece will focus on the origins, early development of, and responses to ladies' Gaelic football in the late 1960s and into the 1970s. In so doing, this piece will aim to bring the historiography of women in Irish society in conversation with the growing historiography on sport in Ireland.

\section{The Origins of Ladies' Gaelic Football}

The hon. sec. of the Dublin Senior Co. Board writes that the ladies' Gaelic football match announced to be played at St. James's Park on Sunday next has not been sanctioned - nor

\footnotetext{
${ }^{9}$ Letter to the Editor, 'Keep Women Out of Croke Park!', Sunday Independent, 27 August 1967, 14.

${ }^{10}$ Gemma Hussey, Ireland Today: Anatomy of a Changing State (Dublin: Townhouse, 1993), 421.

${ }^{11}$ Rosemary Cullen Owens, A Social History of Women in Ireland (Dublin: Gill \& Macmillan, 2005), 55.

${ }^{12}$ Caitríona Beaumont, 'Gender, Citizenship and the State in Ireland, 1922-1990', in Ireland in Proximity:

History, Gender and Space, eds. Scott Brewster, Virginia Crossman, Fiona Beckett and David Alderson

(London: Routledge, 1999), 101.

${ }^{13}$ The Present Duty of Irishwomen: The Contribution of Irish Women as documented in the Archival Record, Irish Archives Resource Portal, accessed 18 October 2020, http://www.iar.ie/Docs/The\%20Present\%20Duty\%20of\%20Irishwomen.pdf.

${ }^{14}$ Diarmaid Ferriter, The Transformation of Ireland (London: Profile Books, 2005), 666.
} 
would it be sanctioned under any circumstances by the Senior County Board and he further states that any member of the G.A.A. officiating or assisting will be suspended. ${ }^{15}$

The above notice denouncing ladies' Gaelic football appeared in the Evening Herald (Dublin) in September 1920. This instruction from the Dublin Senior Co. Board is interesting for two reasons; firstly, it suggests that ladies' Gaelic football was played in some form four decades before it became popular at festivals in the 1960s and, secondly, the fact that a county board felt obliged to publicly renounce this match typifies the hostility towards women playing contact sports at that time. According to the L.G.F.A., a parish league took place in Cooraclare, county Clare in 1926 and continued for a number of years; ${ }^{16}$ Francis Quill and Pat Chapman, who were involved in the L.G.F.A. at an administrative level and prepared a document on the history of the association for the L.G.F.A. in 2006, claim that a ladies' Gaelic football match took place as early as 1911 in Monaghan between two local camogie teams as part of a fundraising effort for 'Redmond's Home Rule Campaign'. The game ended in an 'un-holy row' when it was discovered that the winning goal was scored by a man named Quigley who had disguised himself as a woman. ${ }^{17}$ More historical research is required to confirm this anecdotal account - however, the appearance of the notice in the Evening Herald in 1920 indicates that the idea of ladies' Gaelic football existed in some form in the early decades of the twentieth century. The position taken by the Dublin county board was not unlike the official position taken by the Football Association (F.A.) in England, who went so far as to ban women's football (also known as soccer) from being played on any pitches owned by clubs associated with the F.A. in the 1920s. This ban had the effect of restricting the growth of the game for women, and reflected a wider desire by some in British society to return to a pre-war model of social, political and economic order. Such actions did not prevent women's liberation, however slowly. This was also broadly the pattern in Ireland which, following partition and then independence, sought to embrace some aspects of modernity. Changing gender roles and expectations - and resistance to these-were one aspect of this modernisation.

Organised and competitive ladies' Gaelic football matches began to appear with prominence in the late 1960s at carnivals and festivals across the country. The attraction of the game was alluded to in an article published in the Ulster Herald (Omagh) in May 1969. Promoting an upcoming 'Ladies football tourney' at a carnival in county Tyrone, it declared 'it should be a star attraction, particularly with the men' ${ }^{18}$ Over the course of three weekends, the tournament, taking place at St Patrick's Park, Omagh, would welcome four teamsNewtownstewart, Carrickmore Youth Club, Fintona, and Tyrone County Hospital — and would be refereed by a Miss Eileen McBrearty of St. Brigid's Secondary School. It appears that ladies' Gaelic football was quite popular in Tyrone then, as at least two separate carnival tournaments took place in the previous summer. Elsewhere in Ulster, a report on the July 1968 Mountfield Sports Day noted that the 'Ladies tourney' was the highlight of the programme of events and 'aroused great interest among the large attendance'. ${ }^{19}$ Similar tournaments took place throughout Ireland in the late 1960s and into the 1970s. However, not all received positive interest. An application to include a 'crazy women's football match' at the Manulla minifestival in county Mayo induced some apprehension, and the organisers were brought before Balla Court in 1970 to clarify their intentions, illustrating the lower standing and novel nature of women's sport. ${ }^{20}$ In Waterford, on the other hand, an extensive tournament involving twenty

15 'The Ladies Football Match (Gaelic)', Evening Herald, 17 September 1920, 3.

16 'The Beginning', The Ladies Gaelic Football Association, accessed 20 October 2020, https://ladiesgaelic.ie/the-lgfa/history/the-beginning/.

${ }^{17}$ Quill and Chapman, 'Where did it all begin?'.

18 'Ladies Football Tourney', Ulster Herald, 31 May 1969, 14.

19 'Ladies Tourney was highlight of Mountfield Sports', Ulster Herald, 20 July 1968, 8.

20 'Crazy Women's Football Game in Manulla', Mayo News, 1 August 1970, 6. 
teams was run over a number of weeks in 1970, reflecting a thriving community. Revising the rules of men's Gaelic football to allow for the picking up of the ball directly from the ground and prohibiting the shoulder charge, teams of ten, made up of single and married women, competed against each other - in fact, in the final of this tournament the captains of the opposing teams, Kill and Bunmahon, were sisters. ${ }^{21}$ These carnival and festival tournaments were central to the progression of ladies' Gaelic football from a novelty act to a competitive, regulated and more serious sport. Their impact can be measured by the inclusion of the game at a competitive sports day known as 'Offaly Day', run by the Offaly Association in 1973, which saw twenty-eight teams and 280 participants compete in hurling, Gaelic football, ladies' netball, and ladies' Gaelic football. Calling on other county associations and the G.A.A., the Offaly Association Public Relations Officer Sean Donegan told them to 'take a leaf from the Offalymen's book and organise similar ventures which cater for both men and women, county and city, participants'. ${ }^{22}$

By the early 1970s, ladies' Gaelic football appears to have been more firmly established in many counties on the back of these carnival tournaments-albeit on a small, local scale. There is evidence that between the late 1960s and 1973, the game was being played, or had been played, in at least sixteen counties with teams arising out of local parishes (and tournaments) or within existing G.A.A. clubs, workplaces, as well as the network of county associations in Dublin which operated as an outlet for socialising and business for nonDubliners living in the county. ${ }^{23}$ According to Chapman, parish sports day or factory leagues were organised in Fermanagh and in the border area between the 1950s and 1970s. ${ }^{24}$ Similarly, in Tipperary in 1969, a Dan O'Mahoney, working for Bulmers, organised a charity ladies' Gaelic football tournament which saw participation from teams from local businesses and offices such as the Post Office, the County Council and Showering's and Schiessers; in 1972, a fundraiser match between the Drangan and Mullinahone Irish Countrywomen's Association (I.C.A.) guilds in Tipperary also took place. ${ }^{25}$ Most popular in the counties of Roscommon, Kerry, Cork, Offaly, Tipperary, and Waterford, tournaments were regularly held in these areas such that there were some of the earliest counties to establish official county boards for ladies' Gaelic football, separate from and independent to the existing G.A.A.'s county boards. It is believed that the Waterford and Tipperary county boards were formed as early as 1971 or 1972. ${ }^{26}$ Led by Jim Kennedy as Chairperson, the Tipperary County Board oversaw the running of tournaments and had at least six affiliated clubs. However, marriage and work commitments often posed problems when it came to fielding full teams. For example, on their way to the Killurney tournament in 1972 with just fourteen players, the Drangan contingent picked up a young woman who was hitchhiking her way to watch the tournament — but by the time they reached the pitch, she was a committed Drangan player who played her role in their victory that evening. ${ }^{27}$

\footnotetext{
21 'Ladies' Night at Kill', Irish Press, 2 September 1970, 20.

${ }^{22}$ The Countyman, 'News from County Groups', Evening Herald, 6 July 1973, 11.

${ }^{23}$ An analysis of various newspapers and the submissions on www.ladiesgaelic.ie shows that, apart from the counties mentioned already in this chapter and the counties involved in the first All-Ireland championship in 1974, Ladies' Gaelic football was also played informally in Armagh, Meath, Westmeath, Leitrim, Kildare, and Fermanagh in the late 1960s and early 1970s.

24 'History of Ladies' Gaelic football in Fermanagh', The Ladies Gaelic Football Association, accessed 2

December 2017, www.ladiesgaelic.ie.

25 'History of Ladies' Gaelic football in Tipperary', The Ladies Gaelic Football Association, accessed 2

December 2017, www.ladiesgaelic.ie.

26 Ibid.

27 Ibid.
} 


\section{From 'Novelty Act' to National Association}

If proponents of the game of ladies' Gaelic football wished to be taken seriously in the same vein as already established Gaelic games such as hurling, camogie and Gaelic football, then organising the game on an intercounty scale would be imperative. Such a structure was facilitated along the border areas of South Tipperary, Waterford, and Limerick when clubs from neighbouring counties competed against each other at tournaments. Following the success of their respective county championships in Waterford and Tipperary in 1971, an inter-county match was arranged by Father Percy Aherne (Waterford), Jim Kennedy and Jim Donovan (Tipperary). Played at Ballypatrick, county Tipperary, the Tipperary contingent beat the Waterford outfit by a couple of points in what was possibly the first ever officially recorded intercounty ladies' Gaelic football match. ${ }^{28}$ A similar venture in late 1973 saw a Kerry county team invited to take on a Cork team at a festival in Banteer, county Cork. ${ }^{29}$ Mick Fitzgerald, a founding member of the L.G.F.A. and a key figure in the growth of ladies' Gaelic football in Kerry, recounted to the G.A.A. Oral History Project how Bridie Brosnan (Cork) and Mary Geaney (Kerry) starred in an exciting game which was refereed by Cork footballer Denny Long and attracted between one and two thousand spectators and which Kerry won marginally: 510 to $4-11 .^{30}$

However, a significant turning point for official recognition of, and for, ladies' Gaelic football occurred in the summer of 1973 when Brendan Martin of Offaly, a key figure in the Offaly Association in Dublin, organised a match between Offaly and Kerry. In the absence of a national association, this game was billed by the Evening Herald (Dublin) as the ladies' Gaelic football All-Ireland final of 1973. In the run up to the game, the newspaper commended the 'boundless' enthusiasm of the women whose 'dedication is most keen and the standard of their play is a marvel to those who thought that a leather ball and frail feminine fingers were incompatible'. ${ }^{31}$ Shedding light on the organisation of the game in Offaly and Kerry, the article notes the importance of the county associations in Dublin which conduct training sessions in Phoenix Park and Fairview Park for women from these counties who work in Dublin. In Kerry the game was mostly organised in Tralee and the Gaeltacht area of the Dingle Peninsula, but without any official recognition from the men's county board; similarly, in Offaly there were eight ladies football clubs 'loosely associated with the local G.A.A.' but the absence of a county league or championship for the women waslabelled 'an urgent matter for the powers-that-be' by the Evening Herald. ${ }^{32}$ The paper noted too that the Offaly County Board was cooperating with the promoters of the game by including it on its fixture list for 29 July, scheduling the ladies' game in between a football match and a hurling match. This support from the Offaly County Board was significant as it ensured that the game would be exposed to the wider Gaelic games community in Offaly. As alluded to in the Evening Herald, getting public and official recognition for the game was difficult. Therefore, the inclusion of a competitive intercounty ladies' Gaelic football match alongside Offaly club fixtures was noteworthy for its acceptance of the game, while media attention was essential to aid the game's wider promotion. Indeed, the Evening Press (Dublin) post-match report acknowledged the 'two dedicated teams' who proved that they have 'little to learn from their male counterparts' and admitted that many of those who had come to jeer at women playing Gaelic football left the ground in admiration. ${ }^{33}$

\footnotetext{
28 'The Beginning', The Ladies Gaelic Football Association.

${ }^{29}$ Quill and Chapman, 'Where did it all begin?'.

${ }^{30}$ Mick Fitzgerald, interview for G.A.A. Oral History Project, 11 April 2011, accessed 29 May 2018, https://www.gaa.ie/the-gaa/oral-history/mick-fitzgerald/

31 'Offaly v. Kerry in July', Evening Herald, 24 July 1973, 18.

32 Ibid.

${ }^{33}$ Paul Rouse, 'The long battle towards equality for the ladies' game', Irish Examiner, 22 September $2017,33$.
} 
As Offaly were crowned unofficial All-Ireland champions, this fixture gave ladies' Gaelic football a platform to build on and proved that the game was alive and kicking.

Accordingly, 1974 was a decisive year in the development of ladies' Gaelic football. Recognising that a governing body would have to be established if the sport was to progress nationally, Kennedy organised a meeting in Hayes Hotel, Thurles in July 1974 with that purpose in mind. Although the turnout for the meeting was low, Kennedy had received letters of interest from eight counties which warranted enough enthusiasm for the L.G.F.A. to be established and for a senior intercounty championship to be held. Key figures such as Jim Kennedy (President, Tipperary), Marie McAleer (Vice-President, Roscommon), Mary Nevin (Honorary Secretary, Offaly), Joe Feighery (Assistant Secretary, Offaly), Margaret Flanagan (Treasurer, Roscommon) and Brendan Martin (Assistant Treasurer, Offaly) assumed positions on that first L.G.F.A. board and were instrumental to the progress made by ladies' Gaelic football in its early years. The L.G.F.A.'s decision to adopt the descriptor 'ladies' rather than 'women's' in the association's title is significant given the social mores of the time. It is unclear to what extent the nomenclature of the association was discussed or if arguments were put forward against the use of the label 'ladies' at that first meeting, or thereafter, but it likely reflects a desire to attach a 'ladylike' image to the game.

It was decided that the four Munster counties-Cork, Kerry, Tipperary, and Waterford-would compete for the Munster title while Roscommon were drawn against Laois and Offaly against Galway. The first ever Munster final, which also doubled as an All-Ireland semifinal, saw Tipperary take on Kerry and win by a solitary point on a score line of 2-6 to 25, while Offaly overcame Laois in the other semifinal. The fact that Laois ran the more experienced Offaly side close, despite not having a county board until 1976 and having issued an open call for county players, was commendable. However, the L.G.F.A.was concerned about the lack of media coverage given to the upcoming All-Ireland final and a press conference was called at Hayes Hotel on the Thursday evening prior to the final. The Evening Press and the Irish Press (Dublin) both ran post-match pieces on the final, praising the players who 'dispelled any illusions that this kind of sport is not for the gentle sex', with the game even featuring on the front page of the Irish Press. ${ }^{34}$ Dan Coen, reporter with the Irish Press, described the match as 'tough and fast' and quoted referee Paul O'Sullivan as saying that the play was 'not without a good deal of expertise'. ${ }^{35}$ Tipperary held a 1-2 to 0-0 lead for much of the first half, but the teams left the field at halftime level at 1-2 each before Offaly scored a goal on the restart. Nevertheless, Tipperary battled back to go one point ahead through a free kick with eight minutes to go and were crowned the first official ladies' Gaelic football AllIreland Champions on a score line of $2-3$ to $2-2$. In what was described as 'a noble gesture' and a 'nice "ladylike" touch', Offaly captain Agnes O'Gorman presented the cup to Tipperary captain, Kitty Ryan. ${ }^{36}$ Coen noted in his post-match report that the game 'had not the huge crowds [but] . . . had all the enthusiasm and thrills of many an All-Ireland in Croke Park'. ${ }^{37}$ The positive reception of the game was further reinforced by the newspaper's call for more counties to join the championship the following year and for the next All-Ireland final to be played in Croke Park. A low-scoring but lively affair, the 1974 All-Ireland final marked the official arrival of the L.G.F.A and an early growth spurt.

\footnotetext{
34 'Hats off to the girls of Laois!', Evening Press, 14 October 1974; Dan Coen, 'All-Ireland "first" for the Women', Irish Press, 14 October 1974, 1.

${ }^{35}$ Coen, 'All-Ireland "first"'.

36 Ibid.

${ }^{37}$ Ibid.
} 


\section{The early development of the L.G.F.A., 1974-82}

While just eight counties competed in the first senior intercounty championship in 1974, at least a further seven counties established county boards in the 1970s: Cavan, Mayo, Wexford, Armagh, Meath, Kilkenny and Leitrim (although the game declined in Armagh, Meath and Kilkenny in the latter years of the decade and was not revived until the 1990s). A further four counties, all from the province of Leinster-Dublin, Wicklow, Kildare, and Longford - set up county boards in the 1980s. Local and provincial newspapers illustrate the growth of the game within individual counties. The Nationalist and Leinster Times (Carlow) reported in January 1976 that there were eleven clubs in Laois and that the county team and reigning Leinster champions were intent on achieving All-Ireland glory in $1976 .{ }^{38}$ In Mayo, the Connacht Tribune (Galway) attended the annual dinner dance of the Mayo Ladies County Board and noted that 'although the organisation is but a young one in the county, there was much to celebrate' ${ }^{39}$ Chairman Reverend Gerry Gillespie stated that while the association was still in its infancy and struggling somewhat, "with the expected level of support he was confident they would progress'. ${ }^{40}$ There were notices placed in newspapers throughout 1976 calling for expressions of interest in founding ladies' Gaelic football teams or entering tournaments in the counties of Kildare, Louth, Meath, Westmeath, Kilkenny and Kerry. ${ }^{41}$ Whether they were promoting a county league or a carnival tournament, the notices demonstrate the growing popularity of the game and the appetite amongst girls and women to play. The L.G.F.A.'s decision to launch an intercounty All-Ireland Under-16 championship series in 1976, followed by an All-Ireland senior club championship in 1977, highlights that the playing base had increased, and such competitions were in demand. More significantly, however, the introduction of these competitions unveiled a longer-term strategic vision for the L.G.F.A.; a vision which was notable in that it, firstly, aimed to encourage more teenage girls to play Gaelic football and, secondly, promoted the playing of Gaelic football among girls and women in their local communities. This sentiment was echoed by the Roscommon Ladies County Board who sought to set up a seven-a-side competition between local secondary schools in 1977. In 1974 they had received a letter from a young girl in Boyle of just eleven years, who hoped that someone would set up a team in her area, indicating that there was interest amongst some preteens in playing the game. ${ }^{42}$ Indeed, in 1977 thirteen year-old Bernie Callaghan played on Cavan's All-Ireland-winning senior and Under-16 county teams. ${ }^{43}$ Referring to it as an 'urgent' matter, the Roscommon board noted that although there may be some opposition to the schools' competition, it was important to introduce young girls to the game as early as possible so that they could grasp the basic skills. ${ }^{44}$

Although ladies' Gaelic football prospered in Munster, as seen through the growth in the number of clubs and county teams, as well as parts of Leinster and Connacht, the game was constrained in its development by particular sociopolitical conditions in the North of Ireland.

\footnotetext{
38 '11 Womens' Clubs in Co. Laois', Nationalist and Leinster Times, 9 January 1976, 9.

39 'Mayo Ladies Look to the Future', Connacht Tribune, 16 January 1976, 10.

${ }^{40}$ Ibid.

41 'Ladies Football', Nationalist and Leinster Times, 6 February 1976, 18; 'Fair Sex is Football Crazy', Drogheda Independent, 28 May 1976, 17; 'Ladies' Football', Meath Chronicle, 21 August 1976, 6; 'Good Response to Ladies Football', Westmeath Examiner, 4 September 1976, 13; 'Now tug-o-war for ladies', Kilkenny People, 8 October 1976, 13; 'Ladies Football Alive and Well', Kerryman, 21 May 1976, 7. ${ }^{42}$ Minutes from the Roscommon Ladies County Board meeting at St. Colman's Club, 22 July 1974, private papers of Marie McAleer.

43 'History of Ladies' Gaelic football in Cavan', The Ladies Gaelic Football Association, accessed 10 February 2018, www.ladiesgaelic.ie.

${ }^{44}$ Minutes from the Roscommon Ladies County Board meeting at Percy French Hotel, 27 October 1976, private papers of Marie McAleer.
} 
Enveloped by the military, political and cultural conflict known as the 'Troubles' for much of the last three decades of the twentieth century, it was difficult for ladies' Gaelic football to develop in Ulster. Indeed, it is noticeable that the game was underdeveloped, by comparison, in the border counties of Donegal, Sligo, Monaghan and Louth in this period too. Although there is evidence of ladies' Gaelic football taking place in various counties in Northern Ireland at carnivals and festivals in the late sixties, only two counties from Ulster competed in the senior intercounty championship in the seventies: Cavan and Armagh. Cavan founded their county board in February 1976 and achieved great success in the subsequent years. Winners of the senior and Under-16 All-Ireland titles in 1977, they also contested the Under-16 final in 1979, and the senior and Under-18 final in 1980. Mullahoran, county Cavan won the senior club championship in 1977 and were runners-up in 1978 and 1979. The Armagh county board was established under the guidance of Hugh Meehan in 1976 and were Cavan's only opposition in Ulster for a number of years. However, the county team and county board ceased operations around 1980, leaving Cavan as the only county in Ulster playing ladies' Gaelic football. Armagh attributed the decline of ladies' Gaelic football in the county in this period to a number of factors, including the struggle to get new clubs involved and travel difficulties caused by the 'Troubles' ${ }^{45}$ An Irish Press report from 1974 details how a British Army helicopter landed on the pitch twice within minutes during a ladies' Gaelic football match between Crossmaglen and Culloville in county Armagh. ${ }^{46}$ The British Army had requisitioned Crossmaglen Rangers' G.A.A. grounds in South Armagh as a helicopter base in 1971 and their pitch was often used for landings. Supporters of Gaelic games were also subjected to repeated stop-and-search harassment when travelling to and from games, which often led to delayed start times. Sadly, the harassment also led to the murder of Aidan McAnespie, who was shot by a British soldier at a checkpoint while he was walking to a junior match at Aghaloo in county Tyrone. ${ }^{47}$ These incidents shed some light on the difficulties ladies' Gaelic football and the Gaelic games playing community in general faced in Northern Ireland in this period. Evidently, the 'Troubles' created obstacles for the expansion and playing of Gaelic games in Ulster more generally as, apart from Cavan, no other county competed until the 1990s.

Despite these unique difficulties in Ulster, the growth of the game in other parts of the island meant that it was essential for the L.G.F.A. to devise a standardised charter of rules and objectives for consistency and legitimacy across the organisation. Having originally adopted the G.A.A.'s rules for Gaelic football (around player numbers, pitch size, scoring regime) with slight modifications (prohibition on direct shoulder charge and modified pick-up), the game that was played at carnival tournaments nationwide generally allowed for the picking up of the ball directly off the ground and limited physical contact. However, the necessity of codifying the game was obvious once the national association was established. Indeed, the localised nature of the game meant that the playing rules often differed from county to county and parish to parish. For example, in Tipperary, the game was played with a size four football and allowed for two hops of the ball compared to the traditional one hop and one solo and size five football used by the G.A.A. and adopted by the Roscommon Ladies County Board. ${ }^{48}$ A Central Council meeting held in Portlaoise prior to the commencement of the 1974 championship agreed on a set of forty rules. Generally reflecting the G.A.A.'s rules, the noticeable differences included the official use of a (smaller) size four football, permission to pick the ball directly off the

\footnotetext{
45 'History of Ladies' Gaelic football in Armagh', The Ladies Gaelic Football Association, accessed 2 December 2017, www.ladiesgaelic.ie.

46 'Copter again on the GAA field during game', Irish Press, 22 April 1974, 3.

${ }^{47}$ Cronin, Duncan and Rouse, The G.A.A., 170.

${ }^{48}$ Minutes from the Roscommon Ladies County meeting at Kiltoom, 9 July 1974, private papers of Marie McAleer.
} 
ground, and moving the fifty-yard free kick to the thirty-yard line. ${ }^{49}$ However, the 1977 Chairperson of the Mayo Ladies' board, Lynda Colgan, publicly called for the rules to be revised and 'streamlined' in order to make the game 'more attractive to the players as well as the spectators' ${ }^{50}$ Colgan stated that the present rules were unsatisfactory due to the allowance of 'a great deal of hard physical contact', and said they should focus instead on 'the skill and speed of the game'. ${ }^{51}$ Michael Naughton, Secretary of the Roscommon Ladies County Board, also queried if there should be a revision of the rules in a letter written to the L.G.F.A. in August 1976. Naughton's sentiments agree with Colgan's statement but also give an insight into society's perception of ladies' Gaelic football, stating:

... does the Ladies Gaelic Football Association not consider that some changes are necessary in the playing rules to counter allegations from various quarters that the games as presently constituted for women bears too near a similarity to men's football? Strong doubts have been expressed by medical people, members of the GAA, parents etc. that the game if played strictly in accord (or even with slight modifications) with men's football, would be dangerous on medical grounds; too robust for participation by a great many girls and unattractive as a spectacle! $!^{52}$

Clearly, the idea of women playing Gaelic football did not sit comfortably with some people. It was common for arguments to be put forward against women's participation in sport on medical grounds; for example, it was claimed that cycling would lead to infertility in women, ${ }^{53}$ and there were fears that bruising on a woman's chest caused by a ball could become cancerous. ${ }^{54}$ Dr. Donal Keenan, former President of the G.A.A. and a medical doctor by profession, was concerned that women playing Gaelic football could suffer injuries to the chest area and advocated for protective bras to be worn, similar to bras worn by American sportswomen. ${ }^{55}$ Keenan arranged for these bras to be brought over from America for the Roscommon ladies' team, but Marie McAleer recalls that they laughed at them and, instead of wearing them, hung them out the windows of their cars. ${ }^{56}$ The benefits of wearing a sports bra for breast support and comfort are backed by research today, but the medical myths about the fragility of the female body prevailed for much of the twentieth century and were barriers to women's participation in sport. The amusement the Roscommon ladies' team got from the situation reveals the unique and complex position in which they found themselves, as pioneers within a male-dominated sport which did not really know how to deal with women's physicality, and especially in terms of appropriate dress.

Permitted to wear shorts if they desired to, many teams borrowed jerseys from local camogie teams or men's club teams. A report of a match in the Leitrim Observer in 1978 illustrates the modest beginnings of ladies' Gaelic football and the issue of female dress in sport, noting how three women had complained about 'their jeans being too heavy'. ${ }^{57}$ These accounts tell us that women encountered practical issues with the kit when playing ladies' Gaelic football but there is also evidence that societal gender norms questioned how much

\footnotetext{
${ }^{49}$ Quill and Chapman, 'Where did it all begin?'.

50 'Call for New Rules for Ladies’ Football', Western People, 2 February 1977, 11.

${ }^{51}$ Ibid.

${ }^{52}$ Michael Naughton to (unnamed) Secretary of the L.G.F.A., 24 August 1976, private papers of Marie McAleer.

${ }^{53}$ Hargreaves, 'The Victorian Cult of the Family', 58.

${ }^{54}$ Sheila Fletcher, Women First: The Female Tradition in English Physical Education 1880-1980 (Dover, N.H.: Athlone Press, 1984); cited in Jean Williams, A Game for Rough Girls? A History of Women's Football in Britain (London: Routledge, 2003), 29.

55 Tom Rowley, 'Doctor's warning for those high-kicking women footballers', Irish Independent, 19 May 1977, 3.

${ }^{56}$ Marie McAleer, interview for G.A.A. Oral History Project, 22 November 2010, accessed 29 May 2018, https://www.gaa.ie/the-gaa/oral-history/marie-mcaleer.

57 'Creating A Stir!', Leitrim Observer, 19 August 1978, 16.
} 
women's bodies should be revealed in public through physicality. Tom Inglis has demonstrated, in his work on honour and shame, how women in Ireland have been bound to an honour code based on teachings of the Catholic Church, which has historically focused on their innocence and subservience. ${ }^{58}$ However, Inglis notes that, since the 1970 s, concepts of honourable and shameful behaviour have changed dramatically in Ireland with the decreasing influence of the Catholic Church. In sport, the perceived inferiority of women compared to men has denied sportswomen public honour, according to Katie Liston. Sporting honour has largely been a male preserve, she says, and the struggle to achieve public honour for women's sports is ongoing. ${ }^{59}$

Naughton's letter reveals that traditional ideas concerning male- and femaleappropriate sports were prevalent in the mid-1970s. Despite the L.G.F.A.'s modification of the game to suit gendered norms and different views on women's physicality, it appears that the dominant ideology concerning women's wider social role was also reflected in the early official years of the game. Views differed and it was for many unsuitable, unfeminine, and unattractive. This presented a challenge for the L.G.F.A. Accordingly, a committee consisting of Tom Dowd, Tom Kenny and Ultan Fitzpatrick was appointed by Central Council in 1977 to review the existing rules and put forward a report to both the L.G.F.A. and the G.A.A. (with whom the L.G.F.A. were in talks regarding official recognition) for consideration. A final document titled the 'Charter, Constitution \& Rules of Ladies Gaelic Football Association' laid down 38 points relating to the aims and objectives of the L.G.F.A., as well as specifying the playing rules of ladies' Gaelic football. The charter tackled the issue of women's physicality by prohibiting tripping, kicking, pushing, elbowing, shouldering and pulling; it gave authority to the referee and officials, including the county board, to enact and uphold these rules. This gave the L.G.F.A. some much needed legitimacy in the eyes of a conservative public and the G.A.A.

\section{The Press, the Public and the 'Powers-that-be': Recognising the L.G.F.A.}

In their examination of media sport and women in Ireland, Katie Liston and Mary O'Connor note that, in the expanding research on the topic of media sport and women internationally, Ireland is 'noticeable by its relative absence'. ${ }^{60}$ Further, they assert that the challenges of sexism, stereotyping and gender bias are present in media sport in Ireland and are 'almost intractable 'across time, space and content delivery platforms' ${ }^{61}$ These hurdles undoubtedly constrained the L.G.F.A. and their efforts to promote ladies' Gaelic football in the 1970s. Tom Rowley, a reporter with the Connaught Telegraph (Castlebar) and the Public Relations Officer of the L.G.F.A. in 1976, compiled a document on 'Ladies Football and Press Relations' (year unknown) which shared guidelines on how to attract publicity for the game at a local and national level. Rowley stated in the document that 'publicity, at club, county and national level can play an invaluable role in the promotion of ladies football but obtaining this publicity at present is difficult as the game is very young, ${ }^{62}$ He encouraged the association to develop

\footnotetext{
58 Tom Inglis and Carol MacKeogh, 'The double bind: Women, honour and sexuality in contemporary Ireland', Media, Culture \& Society 34, no. 1 (2012): 68.

${ }^{59}$ Katie Liston, 'Struggle for public honour for women's sport is ongoing', Irish Independent, 1 March 2020, https://www.independent.ie/sport/womens-sport/struggle-for-public-honour-for-womens-sport-is-ongoing39002550.html.

${ }^{60}$ Katie Liston and Mary O'Connor, 'Media Sport, Women and Ireland: seeing the wood for the trees', in Sport, the Media and Ireland, eds. Neil O’Boyle and Marcus Free (Cork: Cork University Press, 2020): 275.

${ }^{61}$ Global Media Monitoring Project Report (2015); cited by Liston and O'Connor in 'Media Sport, Women and Ireland', 283-4.

62 Tom Rowley, 'Ladies Football and Press Relations', date unknown, private papers of Marie McAleer.
} 
strong relationships with local newspapers and reporters and to supply them with information and news. Rowley also advised contacting Jimmy McGee, sports broadcaster at Raidió Teilifís Éireann (RTÉ), to announce fixtures on his Saturday radio slot, and also the local freelance cameraman. While Rowley acknowledged the challenge of raising publicity for a young sporting organisation, the document he prepared does not appear to explicitly take into account those challenges of sexism, stereotyping and gender bias which exist overtly and covertly in media sports. Helen O'Rourke, former President of the L.G.F.A. (1994-1997) and current CEO of the L.G.F.A., recalls how the L.G.F.A. struggled for many years to get Seán Óg Ó Ceallacháin to announce ladies' Gaelic football results on his national radio programme, Gaelic Sports Results, and that Tim O'Connor, head of RTÉ Sport in the 1990s, felt there was no appetite for ladies' Gaelic football matches to be broadcast on television. ${ }^{63}$ Mick Fitzgerald also lamented the lack of attention given by local media in Kerry when they won in the AllIreland final in $1976 .{ }^{64}$ These anecdotes illustrate a resistance to, or a disinterest in, giving media coverage to ladies' Gaelic football from the 1970s through to the 1990s and, while further research and historical analysis of the relationship between the media, women and sport in Ireland is required, there is no doubt that women's sport has been undervalued by the media.

A 'master stroke of publicity' was pulled off by Roscommon in the run up to the 1977 All-Ireland final against Cavan which put ladies' Gaelic football on the front pages. Amongst the Roscommon players was a young woman named Pauline Gibbons who had left for England to join the Augustinian order of nuns prior to the All-Ireland semifinal. She was a key member of the Roscommon team, and the county board wrote to her Mother Superior to ask her to grant (now Sister) Pauline special leave to play in the All-Ireland final. Her Mother Superior duly agreed and joked to Naughton (of the county board) that "we have told Sister Pauline that as well as keeping her eye on the ball to keep her eyes open for vocations, so do not blame me if you are minus many players by next All-Ireland Final'. ${ }^{65}$ 'Big match prayers for Sister Pauline' was the headline that accompanied four photographs on the front page of the Irish Press, and RTÉ News ran a report on Sister Pauline. Despite the prayers said by the nuns at St. George's Convent in Sussex, Roscommon were runners-up and Sister Pauline returned to England to take her vows. According to Naughton, 'the media went to town' when they heard a nun would be lining out for Roscommon, and he maintains that the extensive coverage given to Sister Pauline ensured that over three thousand spectators turned out at Hyde Park, Roscommon for the final. ${ }^{66}$ Certainly, it was positive that the 1977 All-Ireland final received such coverage, however, it is doubtful that the final would have received the same coverage without the profile of Sister Pauline.

Public opposition was also levelled against ladies' Gaelic football. The Southern Star (Skibbereen) carried an article after the 1977 All-Ireland final which conveyed shock at a nun playing ladies' Gaelic football and asked if it was 'a joke or are we meant to take it seriously?'. ${ }^{67}$ The (unnamed) author acknowledged that he may be a 'male chauvinistic pig' but shared his outrage that a nun was partaking in this 'most un-ladylike' activity and worried that convent schools might encourage such behaviour. The author's stance clearly stems from a patriarchal and religious outlook concerning gender roles and stereotypes. His disdain for 'unfeminine' women is obvious:

\footnotetext{
${ }^{63}$ Helen O’Rourke, interview for G.A.A. Oral History Project, 16 July 2013, accessed 29 May 2018, https://www.gaa.ie/the-gaa/oral-history/helen-bourke/

${ }^{64}$ Fitzgerald, G.A.A. Oral History Project.

${ }^{65}$ Letter from Sister Mary Leonie, Reverend Mother to Michael Naughton, 14 October 1977, private papers of Marie McAleer.

${ }^{66}$ Account written by Michael Naughton, 'Ladies Gaelic Football: The Early Years', n.d., private papers of Marie McAleer.

67 'Is it a joke?', Southern Star, 3 December 1977, 19.
} 
In short, I don't like the idea of ladies' soccer or ladies' rugby or ladies' Gaelic football. By definition, no true lady would be seen dead or alive at such functions, but if there are tomboys or over-ebullient girls who like to participate in such activities, then the best of luck to them. ${ }^{68}$

In response to the article, the West Cork Ladies Football Board wrote to the editor of the Southern Star to defend ladies' Gaelic football and to clarify that it is far from a joke. Similar to the letters received by the Sunday Independent ten years earlier, the ladies of West Cork argued that 'for too long ladies have worked behind the scenes performing the less glamours and often thankless chores of the association' and defended their right to 'prove themselves worthy opponents of our national games'. ${ }^{69}$

Aside from the media and the public, there were efforts made to have ladies' Gaelic football recognised by the G.A.A. in the 1970s and early 1980s. McAleer felt that the general consensus amongst L.G.F.A. members in the 1970s was that the G.A.A. 'didn't pass any heed' towards the women's game when it was first established, viewing it as no more than a fad that would fade away. ${ }^{70}$ However, delegates from the L.G.F.A. and the G.A.A. met a number of times in the late 1970s to discuss rules and possible integration; figures involved at these meetings included L.G.F.A. President Tom Kenny (1977-1979, Offaly), G.A.A. President Con Murphy (1976-1979, Cork), G.A.A. General Secretary Seán Ó Siocháin (1964-1979, Cork) and former G.A.A. President Dr. Donal Keenan (1976-1979, Roscommon); as well as L.G.F.A. representatives Paul O'Sullivan (Munster), Thomas Dowd (Ulster) and Lynda Colgan (Connacht). ${ }^{71}$ A press release issued by the L.G.F.A. following a meeting on 25 September 1976 at Croke Park stated that Kenny outlined the aims, progress and activities of the L.G.F.A. and that Murphy 'expressed pleasure at the steady progress of the game in a relatively short time' and hoped that there would be a 'most cordial and helpful relationship' between the L.G.F.A., the Camogie Association and the G.A.A. The press release also outlined some of the topics discussed at the meeting, including the modification of ladies' Gaelic football 'where necessary, to render the game as attractive and safe as possible', the co-existence of ladies' Gaelic football and camogie and medical concerns put forward by Dr. Keenan. The discussion of these issues indicate that the G.A.A. had reservations about recognising ladies' Gaelic football - reservations that appear to conform to gender stereotypes that deemed women and Gaelic football unsafe and incompatible. The press release concluded by saying that the L.G.F.A. were 'happy with the progress made and viewed it as a major step forward' in the recognition of the L.G.F.A. and that a further meeting was being arranged for December of that year. $^{72}$ The G.A.A. officially recognised the L.G.F.A. in 1982 yet it appears to have been an unceremonious affair. Mick Fitzgerald, President of the L.G.F.A. from 1982 to 1985, recalls simply being handed a scroll in the Gresham Hotel by G.A.A. President, Paddy Buggy, to say that the G.A.A. acknowledged the ladies' game. ${ }^{73}$

Without a doubt, the growth of ladies' Gaelic football from the 1970s onwards, including another growth spurt in the 1990s, and the strengthened and reinforced position of the association within Irish sport, were impressive achievements for a young association. That this is the case is clear when one considers that the association had no guidance or support from another sporting body within Ireland or beyond; ladies' Gaelic football was unique to Ireland

\footnotetext{
68 Ibid.

69 'Ladies are no joke', Southern Star, 7 January 1978, 8. The writer of the letter may have meant 'proponents' rather than 'opponents'.

${ }^{70}$ McAleer, G.A.A. Oral History Project; O’Rourke, G.A.A. Oral History Project.

${ }^{71}$ All-Ireland Ladies Football Central Council, Press Release, September 1976, private papers of Marie

McAleer. Tom Kenny acted as the L.G.F.A. representative for Leinster as well as L.G.F.A. President.

72 Ibid.

${ }^{73}$ Fitzgerald, G.A.A. Oral History Project.
} 
but has since developed into a unique case for understanding the development of women's sport internationally. Being the most popular national sport for girls and women, now drawing attendances of over fifty thousand to its premier finals, the game has also since spawned an independent representative players' association for female county players. Determined to create a sport that was accessible and attractive to women, the L.G.F.A. continually strove to do so in the face of many obstacles, whether publicity-related or plain scepticism. The fact that the L.G.F.A. did not immediately succeed in establishing ladies' Gaelic football in thirty-two counties is not surprising considering women had long been excluded from ball games. However, there was most definitely an ambition amongst Irishwomen to play Gaelic football and this desire, along with L.G.F.A. initiatives, was instrumental in the consolidation of ladies' Gaelic football.

\section{Conclusion}

The informal and precarious beginnings of ladies' Gaelic football and the fact that it appeared so long after the establishment of men's Gaelic football illustrate the place of women's sport in Irish society. Furthermore, the formation of the L.G.F.A. and the growth of the game in the 1970s reveals changing social norms at that time. Undoubtedly, the emergence of ladies' Gaelic football as an organised and competitive sport was a momentous development in Irish sport and was symbolic of the improved position of women in Irish society in the 1970s. The growth of the game challenged traditional gender roles, including the belief that women should not play football, confronting a conservative, Catholic, patriarchal society in the process. That is not to say that the game was accepted with open arms. Long-standing arguments against women's sports, based on established gender roles and stereotypes, medical myths and social conservatism presented obstacles to the development of ladies' Gaelic football, as was also the case for soccer and rugby played by women. Nonetheless, discrimination against women's sports is still prevalent and represents a legacy of traditional discrimination against women everywhere. Despite this, the number of girls and women taking part in sport has grown considerably since the turn of the twenty-first century. Ladies' Gaelic football is one of the fastest growing female sports today-L.G.F.A. youth and adult membership had reached approximately 188,000 by 2018 and attendance at the annual All-Ireland intercounty Championship finals has increased considerably in the past three years with a record 56,114 spectators in 2019. A representative body, the Women's Gaelic Players' Association (WGPA) was set up in 2015 for female athletes playing ladies' Gaelic football and camogie at the county level, which has amplified the voice and visibility of these athletes. ${ }^{74}$

In the space of the six years between 1968 and 1974, ladies' Gaelic football transformed itself from a novelty act into a serious and competitive sport with a national association. Although there is evidence that ladies' Gaelic football existed in some shape or form in the early twentieth century, its growth was thwarted by unsupportive social conditions. It took until the late 1960s and early 1970s for Ireland to be sufficiently modernised for women to confront the secondary role prescribed to them by society, including in sport. There was an obvious appetite amongst Irish women to be involved in an active social outlet such as Gaelic football and the role played by carnivals, workplaces, and county associations in facilitating this outlet was instrumental in establishing the game. However, it was the decisions made in 1973 and 1974 to develop the game on an intercounty basis and form a national association which laid

\footnotetext{
${ }^{74}$ Katie Liston and Aoife Lane, 'Sports, Gender, and Representation: The Women's Gaelic Players' Association', in The Business and Culture of Sport: Society, Politics, Economy, Environment, eds. Joseph Maguire, Mark Falcous, and Katie Liston, ed. 1, vol. 3 (New York: Macmillan Reference USA, 2019), 406.
} 
the foundation for the slow but significant transformation of ladies' Gaelic football into a serious enterprise.

Despite difficulties engaging with the public and the media and attaining recognition from the G.A.A., the L.G.F.A. successfully oversaw the growth of the game through the setting up of various intercounty and club competitions, thus increasing the playing base across a broad range of counties and age groups. Although the L.G.F.A. remains an autonomous body, it is acknowledged as a organisation related to the G.A.A., which has helped to gain acceptance in the wider Gaelic Games community. Indeed, Quill and Chapman have asserted that "with the arrival of An Cumann Peil Gael na mBan on the scene, the G.A.A. had attained for the future of its game a great asset'. ${ }^{75}$ The growth and success of the association is exemplified by the fact that the game has grown internationally withclubs across Europe, Asia, America, Canada, Australia, and New Zealand. . None of these achievements would have been possible without the pioneers of the 1970s who broke the cultural mould. In many ways, perhaps the most important achievement of the L.G.F.A. in its early years was successfully developing ladies' Gaelic football into an 'attractive' and legitimate sport for women. Reflective of a changing and modernising Irish society, the establishment of the L.G.F.A. was also a driving force in the growth of women's sports in Ireland from the 1970s onwards. There is no doubt that the L.G.F.A. gave women an opportunity to actively engage in sport, in both a playing and administrative capacity, thus rewriting the role of women in sport in Ireland. Olive Dufficy, the goalkeeper of the All-Ireland-winning Roscommon team of 1978, summed up the pivotal role of those figures and their legacy in a letter read at the thirtieth anniversary celebration of the win in 2008. She said:

What a pioneering group you were!! When we consider that the Ladies GAA is the fastest growing sport in Ireland today, your contribution at its inception is immeasurable. At a time when matches were played on Rugby grounds and the car boot was our changing room, you saw our potential. Roscommon and the Ladies GAA should be, forever, thankful to you. ${ }^{76}$

\section{References}

'11 Womens' Clubs in Co. Laois'. Nationalist and Leinster Times, 9 January 1976.

'Call for New Rules for Ladies’ Football'. Western People, 2 February 1977.

'Copter again on the GAA field during game'. Irish Press, 22 April 1974.

'Crazy Women's Football Game in Manulla'. Mayo News, 1 August 1970.

'Creating A Stir!' Leitrim Observer, 19 August 1978.

'Fair Sex is Football Crazy'. Drogheda Independent, 28 May 1976.

'Falcarragh Festival Fortnight'. Donegal News, 6 July 1968.

'Farranfore sports meeting is being revived on Sunday'. Kerryman, 14 September 1968.

'Good Response to Ladies Football'. Westmeath Examiner, 4 September 1976.

'Hats off to the girls of Laois!'. Evening Press, 14 October 1974.

'Is it a joke?' Southern Star, 3 December 1977.

'Keep Women Out of Croke Park!' Sunday Independent, 27 August 1967.

\footnotetext{
${ }^{75}$ Quill and Chapman, 'Where did it all begin?'

${ }^{76}$ Letter written by Olive Dufficy, read aloud in 2008, private papers of Marie McAleer.
} 
'Ladies are no joke'. Southern Star, 7 January 1978.

'Ladies' Football'. Meath Chronicle, 21 August 1976.

'Ladies Football'. Nationalist and Leinster Times, 6 February 1976.

'Ladies Football Alive and Well'. Kerryman, 21 May 1976.

'Ladies Football Tourney'. Ulster Herald, 31 May 1969.

'Ladies' Night at Kill'. Irish Press, 2 September 1970.

'Ladies Tourney was highlight of Mountfield Sports'. Ulster Herald, 20 July 1968.

'Mayo Ladies Look to the Future'. Connacht Tribune, 16 January 1976.

'No shortage of novelty events'. Drogheda Independent, 14 August 1970.

'Now tug-o-war for ladies'. Kilkenny People, 8 October 1976.

'Offaly v. Kerry in July'. Evening Herald, 24 July 1973.

'Portarlington'. Nationalist and Leinster Times, 8 August 1969.

'Seventh Annual Field Evening'. Meath Chronicle, 8 June 1968.

'The Ladies Football Match (Gaelic)'. Evening Herald, 17 September 1920.

All-Ireland Ladies Football Central Council. Press Release. September 1976. Private papers of Marie McAleer.

Beaumont, Caitríona. 'Gender, Citizenship and the State in Ireland, 1922 - 1990'. In Ireland in Proximity: History, Gender and Space, edited by Scott Brewster, Virginia Crossman, Fiona Beckett and David Alderson, 94-108. London: Routledge, 1999.

Coen, Dan. 'All-Ireland “first” for the Women'. Irish Press, 14 October 1974.

Countyman, The. 'News from County Groups'. Evening Herald, 6 July 1973.

Cronin, Mike, Mark Duncan, and Paul Rouse. The G.A.A.: A People's History. Cork: The Collins Press, 2009.

Cullen Owens, Rosemary. A Social History of Women in Ireland. Dublin: Gill \& Macmillan, 2005.

Dufficy, Olive. Letter read in 2008. Private papers of Marie McAleer.

Ferriter, Diarmaid. The Transformation of Ireland. London: Profile Books, 2005.

Fitzgerald, Mick. Interview for G.A.A. Oral History Project. 11 April 2011. Audio. Accessed 29 May 2018. https://www.gaa.ie/the-gaa/oral-history/mick-fitzgerald/.

Fitzpatrick, Regina, Paul Rouse, and Dónal McAnallen. 'The Freedom of the Field: Camogie before 1950'. In The Evolution of the GAA: Ulaidh, Éire agus Eile, edited by Dónal McAnallen, David Hassan and Roddy Hegarty, 123-137. Belfast: Ulster Historical Foundation, 2009.

Guttmann, Allen. 'Sports, Politics and the Engaged Historian'. Journal of Contemporary History 38, no. 3 (2003): 363-375.

Hargreaves, Jennifer. 'The Victorian Cult of the Family and the Early Years of Female Sport'. In The Sports Process, edited by Eric G. Dunning, Joseph A. Maguire and Robert E. Pearton, 53-66. Champaign: Human Kinetics Publishers, 1993. 
Hunt, Tom. 'Women and Sport in Victorian Westmeath'. Irish Economic and Social History 34, no.1 (2007): 29-46.

Hussey, Gemma. Ireland Today: Anatomy of a Changing State. Dublin: Townhouse, 1993.

Irish Archives Resource Portal. The Present Duty of Irishwomen: The Contribution of Irish Women as documented in the Archival Record. Accessed 18 October 2020. http://www.iar.ie/Docs/The\%20Present\%20Duty\%20of\%20Irishwomen.pdf.

Inglis, Tom and Carol MacKeogh. 'The double bind: Women, honour and sexuality in contemporary Ireland'. Media, Culture \& Society 34, no. 1 (2012): 68-82.

Ladies Gaelic Football Association. ‘The Beginning'. Accessed 20 October, 2020. https://ladiesgaelic.ie/the-lgfa/history/the-beginning/.

- 'History of Ladies' Gaelic Football in Armagh'. Accessed 2 December 2017.

.'History of Ladies' Gaelic Football in Cavan'. Accessed 10 February 2018.

. 'History of Ladies' Gaelic Football in Fermanagh'. Accessed 2 December 2017.

'History of Ladies' Gaelic Football in Tipperary’. Accessed 2 December 2017.

Liston, Katie. 'Struggle for public honour for sport is ongoing'. Irish Independent, 1 March 2020.

and Aoife Lane. 'Sport, Gender and Representation: Women's Gaelic Players' Association'. In The Business and Culture of Sport: Society, Politics, Economy, Environment, edited by Joseph Maguire, Mark Falcous, and Katie Liston, $1^{\text {st }}$ ed., vol. 3, 399-411. New York: Macmillan Reference USA, 2019.

— and Mary O'Connor. 'Media Sport, Women and Ireland: seeing the wood for the trees'. In Sport, the Media and Ireland, edited by Neil O'Boyle and Marcus Free, 271-307. Cork: Cork University Press, 2020.

McAleer, Marie. Interview for G.A.A. Oral History Project. 22 November 2010. Audio. Accessed 29 May 2018. https://www.gaa.ie/the-gaa/oral-history/marie-mcaleer/.

Minutes from the Roscommon Ladies County Board meeting at Kiltoom .9 July 1974. Private papers of Marie McAleer.

Minutes from the Roscommon Ladies County Board meeting at Percy French Hotel. 27 October 1976. Private papers of Marie McAleer.

Minutes from the Roscommon Ladies County Board meeting at St. Colman's Club. 22 July 1974. Private papers of Marie McAleer.

Naughton, Michael. Letter to (unnamed) Secretary of the L.G.F.A. 24 August 1976. Private papers of Marie McAleer.

—. 'Ladies Gaelic Football: The Early Years'. N.d. Private papers of Marie McAleer.

O’Rourke, Helen. Interview for G.A.A. Oral History Project. 16 July 2013. Accessed 29 May 2018. https://www.gaa.ie/the-gaa/oral-history/helen-bourke/.

Rouse, Paul. 'The long battle towards equality for the ladies' game'. Irish Examiner, 22 September 2017.

Rowley, Tom. 'Doctor's warning for those high-kicking women footballers'. Irish Independent, 19 May 1977. .'Ladies Football and Press Relations'. N.d. Private papers of Marie McAleer. 
Reverend Mother, Sister Mary Leonie. Letter to Michael Naughton. 14 October 1977. Private papers of Marie McAleer.

Williams, Jean. A Game for Rough Girls? A History of Women's Football in Britain. London: Routledge, 2003.

Quill, Francis and Pat Chapman. 'Where did it all begin? The Initial History of An Cumann Peil Gael na mBan up to 1974'. 2006. Private papers of Marie McAleer. 